\title{
Regulation under Financial Frictions: A Quantitative Analysis of Taxes versus Tradable Permits
}

\author{
Manish Pandey and Wenbiao Cai \\ Department of Economics Working Paper Number: 2016-01

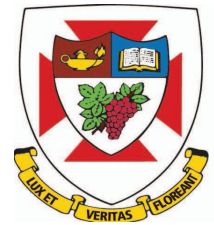 \\ UNIVERSITY OF WINNIPEG \\ Department of Economics \\ 515 Portage Avenue \\ Winnipeg, Canada R3B 2E9
}

This working paper is available for download at: http://ideas.repec.org/s/win/winwop.html 


\title{
Regulation under Financial Frictions: A Quantitative Analysis of Taxes versus Tradable Permits
}

\author{
Wenbiao Cai* $^{*} \quad$ Manish Pandey ${ }^{\dagger}$
}

February 12, 2016

\begin{abstract}
We examine the differential effects of using taxes and tradable permits to regulate emissions in an economy with financial frictions. We construct a two-sector model, where the regulated sector output is produced by entrepreneurs who differ in their endowment of managerial skills and assets and face a borrowing constraint. Government uses either an output tax or sets up a market for permits to restrict emissions by reducing the regulated sector output. We analytically show that tradable permits generate misallocation of resources while taxes do not. We parameterize the model and quantitatively examine the effects of using taxes or tradable permits to restrict the regulated sector output to the same level. We find that compared to taxes, using tradable permits results in lower aggregate productivity, welfare, and government revenue. Our findings suggest that taxes would be a better instrument than tradable permits for regulating emissions in countries with less-developed financial markets.
\end{abstract}

JEL Codes: H23; L52; O44;

keywords: Financial Frictions; Tradable Permits; Taxes; Type-dependent Regulation

*Department of Economics, University of Winnipeg. 515 Portage Avenue, Winnipeg, Manitoba, R3B2E9, Canada. Phone: 1-204-258-2984; fax: 1-204-772-4183; email: we.cai@uwinnipeg.ca.

${ }^{\dagger}$ Department of Economics, University of Winnipeg. 515 Portage Avenue, Winnipeg, Manitoba, R3B2E9, Canada. Phone: 1-204-786-9289; fax: 1-204-772-4183; email: m.pandey@uwinnipeg.ca. 


\section{Introduction}

Regulations for reducing emissions are implemented using either taxes or tradable permits and, in practice, both these instruments are in use. While tradable permits (cap-and-trade) are used by Australia and New Zealand, a carbon tax is used by the province of British Columbia in Canada and various European and Scandinavian countries. The consensus in the literature is that, absent frictions, taxes and tradable permits are equivalent in the provision of incentives for reducing emissions (Weisbach, 2009; Goulder and Schein, 2013).

In this paper we study the differential effects of using taxes and tradable permits to reduce emissions in an economy with financial frictions. ${ }^{1}$ Many developing countries are currently in the process of developing environmental regulations for reducing emissions and therefore face a choice between tradable permits and carbon taxes. ${ }^{2}$ A prominent feature of these countries is the under-development of their financial markets (Rajan and Zingales, 1998; Beck et al., 2000). On the one hand, work by Banerjee and Duflo (2014) and Midrigan and Xu (2014) provides convincing evidence that financial frictions generate misallocation of productive resources across production units, and consequently lower efficiency. ${ }^{3}$ On the other hand, to our knowledge, there is no quantitative research that examines the consequences of using different instruments for regulating emissions in an economy with financial frictions. We fill this gap in the literature.

To guide our analysis, we construct a model that has two sectors: a regulated (polluting) sector and an unregulated sector. In the regulated sector, output is produced by entrepreneurs who differ in their endowment of assets and managerial skills. We introduce financial frictions as an exogenous borrowing constraint faced by entrepreneurs. We assume that emissions are proportional to output in the regulated sector, therefore to restrict emissions the government could either (1) impose a tax on regulated sector output or (2) issue

\footnotetext{
${ }^{1}$ Studies have found differences in the ease of implementation and consequences of using the two instruments for reducing emissions in developed countries. It has been argued that, relative to taxes, using tradable permits is more politically feasible (Keohane, 2009), it has higher administrative costs (Goulder and Schein, 2013) and results in greater uncertainty regarding level of emissions and prices (Nordhaus, 2007). We abstract from these issues in this paper.

${ }^{2}$ See Liu et al. (2013) for a detailed discussion on China.

${ }^{3}$ For a review of the literature on misallocation, see Restuccia and Rogerson (2013).
} 
tradable permits for producing regulated sector goods.

We first analyze the equilibrium allocations of the model without borrowing constraints. In this case, taxes and tradable permits generate identical allocations and therefore are equivalent for reducing emissions. We then show that, because taxes and tradable permits interact differently with financial frictions, this equivalence breaks down when entrepreneurs face borrowing constraints. With taxes, only entrepreneurs with high managerial skills produce regardless of endowment of assets. This is no longer true with tradable permits: an entrepreneur with high managerial skill would not produce if she has low assets to finance capital and permits. In contrast, a low-skill entrepreneur with high assets may find it profitable to produce. Therefore, with permits a larger fraction of regulated sector output is produced by entrepreneurs with low managerial skills. Compared to an economy with taxes, this misallocation translates into lower total factor productivity (TFP), higher price of the regulated good, lower welfare, and lower government revenue in an economy with tradable permits.

We parameterize the model to quantitatively examine the differences in implications of using taxes and tradable permits for reducing emissions. Parameters for preferences over regulated and unregulated goods are based on expenditure shares data. We use data on external finance to GDP ratio to discipline the borrowing constraint. For distributions of assets and managerial skills of entrepreneurs, we assume they both follow marginal distributions that are Fréchet, and in the baseline case consider independent draws. With the parameterized model, we conduct a constant-output experiment as follows. We first solve for equilibrium allocations in a model economy with a tax on regulated sector output that is equal to 7.5 percent, which is the average carbon tax in the province of British Columbia in Canada. We then choose the quantity of tradable permits such that in the economy with permits, which is otherwise identical to the one with tax, the same output (and emissions) is produced in the regulated sector as in the tax economy. We then compare the two economies in terms of TFP, relative prices, government revenue and welfare.

We find that regulated sector TFP is 11 percent lower in the economy with tradable permits. This is because, relative to the tax economy, low-skill entrepreneurs account for a 
larger share of output in the permit economy. To compensate for lower average managerial skills, more capital and labor are employed to produce the same regulated sector output in the permit economy. Since the two economies are identical in endowments, this implies that the permit economy also produces less unregulated output. As a result, welfare is 0.6 percent lower in the permit economy. Moreover, we show that government revenue as a share of GDP for the permit economy is only about half that of the tax economy. We conclude that in the presence of financial frictions, regulating emissions through tradable permits is less efficient than taxes and generates lower government revenue.

We experiment with different parameter values and find that that the differential effects of taxes and permits are more pronounced when the borrowing constraint is uniformly tighter, when high-skill entrepreneurs are more likely to have low assets, and when the government faces a bigger emission reduction target. Our findings suggest that taxes would be a better instrument than tradable permits for regulating emissions in countries at their early stages of development.

Two recent studies provide evidence for the importance of considering financial constraints when examining the effects of environmental regulations, and, therefore, lend support to the mechanism proposed in this paper. Using data for the $\mathrm{SO}_{2}$ program in the United States, Dardati and Riutort (2015) find that in the presence of financial constraints, emission permits result in lower capital expenditures of firms. Andersen (2015) argues that financial frictions distort technology upgrading, and consequently result in higher pollution emissions. Using cross-country panel data for credit reforms and pollution, the study finds evidence that reducing financial constraints results in a reduction in emissions.

In terms of the method used for the analysis, our paper is closely related to Tombe and Winter (2015). They quantitatively analyze environmental regulations implemented using either industry standards or taxes in a model with heterogenous producers. They find that, relative to output taxes, restricting emissions using energy intensity standards results in misallocation of output which reduces aggregate productivity. The focus of this paper, however, is on the differences in implications of using tradable permits and taxes for restricting emission in an economy with financial frictions. 
The rest of the paper is organized as follows. Section 2 presents the model and analytical results. Section 3 provides quantitative results. Section 4 concludes.

\section{Model}

The model economy has two sectors: a regulated sector $(R)$ and an unregulated sector $(U)$. Each sector produces a single consumption good. There is a stand-in household comprised of measure one identical workers and measure one entrepreneurs. Each worker in the household is endowed with one unit of productive time that is supplied inelastically. Each entrepreneur is endowed with asset $a$ and managerial skill $z$, which are random realizations from a joint distribution $F(a, z)$ with marginal distributions $G(a)$ and $H(z)$.

Preferences The household has the following utility function

$$
U\left(C_{U}, C_{R}\right)=\left[\eta\left(C_{U}\right)^{\frac{\epsilon-1}{\epsilon}}+(1-\eta)\left(C_{R}\right)^{\frac{\epsilon-1}{\epsilon}}\right]^{\frac{\epsilon}{\epsilon-1}}
$$

where $C_{R}$ and $C_{U}$ is consumption produced in the regulated and unregulated sector respectively, and $\eta$ and $(1-\eta)$ their respective weight in the utility function. The parameter $\epsilon$ captures the elasticity of substitution between the two consumption goods.

Technology In the unregulated sector, production requires capital $(k)$ and labor $(n)$. For simplicity, we assume that all production in this sector is carried out by a representative firm using the following technology:

$$
y=k^{\alpha} n^{1-\alpha}
$$

In the regulated sector, each entrepreneur produces output combing her managerial skill $(z)$, capital, and labor as follows: $y(z)=(z k)^{\alpha} n^{1-\alpha}$. For simplicity, we assume that emissions are a constant fraction of the regulated sector output, and hence reduction in output of the sector results in lower pollution. Entrepreneurs face a financial constraint of the following form: an entrepreneur with asset $a$ can at the most borrow $\lambda a$ in the financial market. The 
parameter $\lambda>0$ captures the degree of leverage available in this economy. In particular, $\lambda=\infty$ corresponds to a frictionless economy.

The household owns all factors of production, and makes all economic decisions. There are competitive rental markets for capital and labor, and competitive markets for consumption goods.

\subsection{Regulation}

To reduce emissions a government restricts output of the regulated sector using either tradable permits or output taxes. In paragraphs below, we describe the set up and optimization problems for an economy with each of these two instruments. We refer to the economy with tradable permits as the permit economy, and the economy with taxes as the tax economy. We begin with the permit economy.

\subsubsection{Permit Economy}

In the permit economy, entrepreneurs in the regulated sector have to purchase permits prior to production, and each permit allows the production of one unit of output. Permits are tradable in the market at price $q$. The government determines the aggregate supply of permits, denoted by $\bar{Q}$, and reimburses revenue from permit sales back to the household via lump-sum transfers.

Optimization In the unregulated sector the representative firm chooses capital, $K_{U}$, and labor, $N_{U}$, to maximize profit, i.e.,

$$
\max _{\left\{K_{U}, N_{U}\right\}}\left(K_{U}\right)^{\alpha} N_{U}^{1-\alpha}-r K_{U}-w N_{U} .
$$


Entrepreneurs in the regulated sector chooses capital $(k)$, labor $(n)$, and the quantity of permits $Q$ to maximize profit, i.e.,

$$
\begin{aligned}
\max _{\{k, n, Q\}} & p A(z k)^{\alpha} n^{1-\alpha}-r k-w n-q Q, \\
\text { s.t. : } & k+q Q \leq \lambda a, \\
& A(z k)^{\alpha} n^{1-\alpha} \leq Q,
\end{aligned}
$$

where $p$ is the price of output in the regulated sector, $w$ and $r$ is the rental price of labor and capital. All prices are expressed relative to goods in the unregulated sector. Both capital and tradable permits have to be purchased prior to production, and the expenditure is financed through borrowing using an entrepreneur's own assets. ${ }^{4}$ We denote the optimal demands for capital, labor and quota by $k(a, z), n(a, z)$ and $Q(a, z)$ respectively, and the associated maximized profit by $\pi(a, z)$.

Income for the stand-in household consists of labor income, capital rental income, profits from entrepreneurs, and government transfers. Let $N_{R}$ denote the measure of labor in the regulated sector, the household's problem is as follows:

$$
\begin{array}{rc}
\max _{\left\{N_{R}, C_{R}, C_{U}\right\}} & U\left(C_{R}, C_{U}\right) \\
\text { s.t : } & p C_{R}+C_{U}=w\left(1-N_{R}\right)+w N_{R}+r \int a d G(a)+\int \pi(a, z) d F(a, z)+T R,
\end{array}
$$

where $T R$ is lump-sum transfer from the government.

The factors market clearings conditions are as follow:

$$
\begin{aligned}
\int k(a, z) d F(a, z)+K_{U} & =\int a d G(a), \\
N_{U} & =1-N_{R} \\
\int n(a, z) d F(a, z) & =N_{R} .
\end{aligned}
$$

\footnotetext{
${ }^{4}$ This assumption is consistent with empirical evidence in Dardati and Riutort (2015), that in the presence of financial constraints, emission permits affect capital expenditures of firms.
} 
The permit market clearance requires:

$$
\int y(a, z) d F(a, z)=\bar{Q}
$$

Market clearing for the goods market requires:

$$
\begin{aligned}
\int y(a, z) d F(a, z) & =C_{R}, \\
\left(K_{U}\right)^{\alpha} N_{U}^{1-\alpha} & =C_{U} .
\end{aligned}
$$

And the government balance condition is as follows:

$$
q \int y(a, z) d F(a, z)=T R
$$

\subsubsection{Tax Economy}

In the tax economy, the government imposes a ad valorem tax on output in the regulated sector. Each entrepreneur that produces in the sector faces a common tax rate $\tau$. The optimization of an entrepreneur with skill $z$ and asset $a$ is given by

$$
\begin{aligned}
& \max _{\{k, n\}} \quad(1-\tau) p A(z k)^{\alpha} n^{1-\alpha}-r k-w n, \\
& \text { s.t. : } \quad k \leq \lambda a .
\end{aligned}
$$

Unlike in the permit economy, only capital expenditure has to be financed through borrowing in the tax economy. Otherwise, the household's problem and the market clearing conditions are the same as in the permit economy, except that there is no market clearing condition for permits and the government budget balance now requires

$$
\tau \int y(a, z) d F(a, z)=T R
$$




\subsection{The Role of Financial Frictions}

Here we discuss the interaction between financial frictions and regulation. Specifically, we show that absent financial frictions, taxes and tradable permits lead to identical equilibrium allocations. When there are financial frictions, however, tradable permits generate misallocation of resources across entrepreneurs, while taxes do not.

\subsubsection{No Financial Frictions $(\lambda=\infty)$}

Consider the profit maximization problem of entrepreneurs in the regulated sector of the permit economy. As long as $q>0$, it must be the case that in equilibrium $(z k)^{\alpha} n^{1-\alpha}=Q$ for any entrepreneur. Then the profit of an entrepreneur is simply given by $(1-q)(z k)^{\alpha} n^{1-\alpha}-$ $r k-w n$. The first order conditions are

$$
\begin{gathered}
(1-q)(z k)^{\alpha} n^{-\alpha}(1-\alpha)=w \\
(1-q)(z k)^{\alpha-1} n^{1-\alpha} \alpha z=r .
\end{gathered}
$$

These first order conditions are identical to those for a tax economy with a tax rate $\tau=q$. It follows that for regulated sector in the permit economy to be the same as that in the tax economy, the government has to choose quantity of permits such that equilibrium

permit price is equivalent to the tax rate. Therefore, if aggregate endowment, technology and preferences are the same between the two economies, so are equilibrium allocations.

It is useful to point out that since permits are tradable, each entrepreneur faces the same price of permit, hence the marginal product of capital and labor is equalized across entrepreneurs. That is, absent financial frictions, tradable permits do not lead to misallocation of resources across entrepreneurs. However, this will no longer be the case when there are financial frictions.

\subsubsection{Financial Frictions $(\lambda<\infty)$}

We first analyze allocations in the tax economy, and then allocations in the permit economy. 
Taxes The entrepreneur's problem when she pays a production $\operatorname{tax}(\tau)$ is ${ }^{5}$

$$
\begin{aligned}
& \max _{\{k, n\}} \quad(1-\tau)(z k)^{\alpha} n^{1-\alpha}-r k-w n, \\
& \text { s.t. : } \quad k=\lambda a .
\end{aligned}
$$

Let $\xi$ be the Lagrangian multiplier associated with the borrowing constraint, the first order conditions are given by

$$
\begin{aligned}
(1-\tau)(z k)^{\alpha-1} \alpha z n^{1-\alpha} & =r+\xi \\
(1-\tau)(z k)^{\alpha}(1-\alpha) n^{-\alpha} & =w \\
k & =\lambda a .
\end{aligned}
$$

Rearranging the terms yields that demand for labor is linear in managerial skill and capital: $n=\left[(1-\tau)\left(\frac{1-\alpha}{w}\right)\right]^{\frac{1}{\alpha}} z k$. With this, the entrepreneur's profit is linear in capital

$$
\left.\pi_{\tau}(z)=[(1-\tau) \alpha)\right]\left(\frac{(1-\tau)(1-\alpha)}{w}\right)^{\frac{1-\alpha}{\alpha}} z k-r k
$$

Therefore, there exists a skill cut-off $\hat{z}_{\tau}$ given by $\pi_{\tau}\left(\hat{z}_{\tau}\right)=0$, such that if $z<\hat{z}_{\tau}$, the entrepreneur is inactive, i.e., $k(a, z)=n(a, z)=0$. The threshold $\hat{z}_{\tau}$ is given by

$$
\hat{z}_{\tau}=\frac{r}{[(1-\tau) \alpha)]\left(\frac{(1-\tau)(1-\alpha)}{w}\right)^{\frac{1-\alpha}{\alpha}}}
$$

Permits The entrepreneur's problem in the permit economy is

$$
\begin{aligned}
& \max _{\{k, n\}} \quad(1-q)(z k)^{\alpha} n^{1-\alpha}-r k-w n, \\
& \text { s.t. : } \quad k+q(z k)^{\alpha} n^{1-\alpha}=\lambda a .
\end{aligned}
$$

\footnotetext{
${ }^{5}$ As will be clear later, entrepreneurs will always borrow up to the limit if they produce. Therefore, in the optimization problem we ignore the cases where the borrowing constraint is not binding.
} 
Note that the permit constraint $(z k)^{\alpha} n^{1-\alpha}=Q$ has been implicitly substituted into the entrepreneur's problem. Let $\psi$ be the Lagrangian multiplier associated with the borrowing constraint, the first order conditions are given by

$$
\begin{aligned}
(1-q-\psi q)(z k)^{\alpha-1} \alpha z n^{1-\alpha} & =r+\psi, \\
(1-q-\psi q)(z k)^{\alpha}(1-\alpha) n^{-\alpha} & =w \\
k+q(z k)^{\alpha} n^{1-\alpha} & =\lambda a .
\end{aligned}
$$

Using the first order conditions, the entrepreneur's profit is given by

$$
\pi_{q}(z)=[(1-q)-(1-q-\psi q)(1-\alpha)]\left(\frac{(1-q-\psi q)(1-\alpha)}{w}\right)^{\frac{1-\alpha}{\alpha}} z k-r k
$$

Therefore, as in the case for taxes, there exists a managerial skill cut-off $\hat{z}_{q}$ such that $\pi_{q}\left(\hat{z}_{q}\right)=$ 0. The threshold $\hat{z}_{q}$ is given by

$$
\hat{z}_{q}=\frac{r}{[(1-q)-(1-q-\psi q)(1-\alpha)]\left(\frac{(1-q-\psi q)(1-\alpha)}{w}\right)^{\frac{1-\alpha}{\alpha}}} .
$$

Comparing the first order conditions for taxes (1) and permits (3) shows the intensive margin through which permits distort allocations. While in the permit economy the optimal choice of both capital and labor is affected by the borrowing constraint $(\psi)$, in the tax economy only the optimal choice of capital is affected by the borrowing constraint $(\xi)$. In particular, relative to taxes, permits result in greater distortion of the decisions of more financially constrained (higher $\psi$ ) entrepreneurs.

A comparison of the thresholds for taxes (2) and permits (4) illustrates the extensive margin through which permit reduces productivity. In the tax economy, the managerial skill cut-off is independent of assets. Therefore, only entrepreneurs with high managerial skills will produce. This is not the case in the permit economy. In particular, a high-skill entrepreneur who would otherwise produce in the tax economy, might not be active in the permit economy if her asset endowment is low and therefore finds it unprofitable to purchase permits and 
produce. It follows that in equilibrium, relative to the tax economy, the permit economy will have a smaller share of high-skill entrepreneurs and lower TFP in the regulated sector. In other words, in the presence of borrowing constraints, restricting regulated sector output (and reducing emissions) using tradable permits results in greater distortions than taxes, and hence the two instruments are not equivalent. In the next section, we parameterize the model and provide some quantitative results for the differential effects of the two instruments.

\section{Quantitative Analysis}

We set the capital share in the production function $\alpha=1 / 3$, which is a value commonly used in the macroeconomics literature. For preferences, we set the weight on the unregulated sector good $\eta=0.8$. This is based on estimates by the United States Bureau of Labor Statistics that the share of expenditure on food and energy is roughly 20 percent. ${ }^{6}$ We assume that goods produced in the two sectors are gross complements, and set $\epsilon=0.75 .^{7}$ With data on external finance to GDP ratios, Moll (2014) estimate that $\lambda=4.2$ for the United States, and roughly 1.2 for less developed countries like India and China. We experiment with a leverage ratio $\lambda=3$, roughly the mid point of values for developed and developing countries.

We assume a flexible joint distribution of asset and managerial skill as follow:

$$
\begin{aligned}
\quad F(a, z) & =C[G(a), H(z)], \\
\text { where } \quad G(a) & =e^{-a^{-\theta_{a}}} \quad \text { and } \quad H(z)=e^{-z^{-\theta_{z}}}, \\
\text { and } \quad C[u, v] & =\frac{-1}{\rho} \log \left\{1+\frac{\left(e^{-\rho u}-1\right)\left(e^{-\rho v}-1\right)}{e^{-\rho}-1}\right\} .
\end{aligned}
$$

The function $C[G(a), H(z)]$ is a Frank copula, which allows for correlation between draws from distributions $G(a)$ and $H(z)$. The parameter $\rho \in(-\infty, \infty) \backslash\{0\}$ determines the extent of the correlation, with a positive (negative) value of $\rho$ representing positive (negative) correlation between the asset and skill. The marginal distributions themselves are Fréchet,

\footnotetext{
${ }^{6}$ Source: http://www.bls.gov/news.release/cpi.htm

${ }^{7}$ Using expenditure data on final consumption, Herrendorf et al. (2013) estimate a similar degree of complementarity between manufacturing and services goods.
} 
with dispersion parameters $\theta_{a}$ and $\theta_{z}$, and scale parameters normalized to one. This specification is similar to that used by Lagakos and Waugh (2013) to model the joint distribution of unobserved skills of workers in agriculture and non-agriculture. The Fréchet distribution in addition allows for a fat right tail in the size distribution of establishments, which is an important feature of the data. ${ }^{8}$ As a initial pass, we set the distribution parameters as $\theta_{a}=\theta_{z}=2$, and consider the case of no correlation between assets and skills. ${ }^{9}$

We conduct the following experiment: for a given tax rate $\tau$, we compute the equilibrium allocations in the tax economy. We then choose the aggregate quantity of permits such that the permit economy produces the same level of output in the regulated sector as in the tax economy. Therefore, from the perspective of reducing emissions by restricting the regulated sector output, taxes and permits are equivalent. We then compare other implications such as productivity, welfare, and government revenue, for these two economies. We compute total factor productivity (TFP) for the regulated sector as follows:

$$
\frac{\int z^{\alpha} y(a, z) d F(a, z)}{\int y(a, z) d F(a, z)} .
$$

Our measure of TFP is simply the output weighted managerial skills of entrepreneurs who produce positive quantity in the regulated sector. Our notion of welfare is simply the maximized household utility. Finally, we compute government revenue from permit sales and taxes, both expressed as a share of aggregate output.

We begin with a tax rate $\tau=7.5 \%$. This is approximately the carbon tax currently in effect in the province of British Columbia in Canada. ${ }^{10}$ Table 1 compares allocations in the tax economy versus the permit economy. By construction both economies produce the same amount of output in the regulated sector. However, the permit economy has a higher share of entrepreneurs producing positive quantity. Relative to the tax economy, TFP for the

\footnotetext{
${ }^{8}$ See Restuccia and Rogerson (2008) and Guner et al. (2008).

${ }^{9}$ Later in this Section we examine the sensitivity of our results to different parameter values. In particular, we present results in cases where managerial skills and asset endowments are positively or negatively correlated.

${ }^{10}$ Depending on their carbon content, the carbon tax in British Columbia differs across goods. However, the tax on fuel ranges between 6.67 and 7.83 cents per litre (source: http://www.sbr.gov.bc.ca/documents_library/bulletins/mft-ct_005.pdf accessed January 21, 2016). This is approximately equivalent to an average tax of $7.5 \%$.
} 
regulated sector is 11 percent lower in the permit economy, which also results in consumers facing a higher relative price of the regulated sector output. The lower regulated sector TFP in the permit economy comes from the fact that more capital and labor are used to produce the same quantity of output. Since aggregate endowment of capital and labor are the same across the two economies, it follows that output produced in the unregulated sector is also lower in the permit economy than the tax economy. As a consequence, welfare is about 0.6 percent lower in the permit economy.

Government revenue as a share of GDP in the permit economy is only half of that in the tax economy. Let $Y_{R}$ denote the equilibrium output in the regulated sector. Government revenue is $q * Y_{R}$ in the permit economy and $\tau * Y_{R}$ in the tax economy. Note again that by construction the output in the regulated sector is the same in both economies. This implies that the equilibrium price of permit is less than the corresponding tax rate, $q<\tau$. The reason is that if the price of permit were equal to the tax rate, less regulated sector output will be produced in permit economy as, in addition to acting as a tax on output, tradable permits distort allocations across entrepreneurs. Consequently, for the permit economy to produce the same amount of regulated sector output as in the tax economy, the equilibrium price of permit must be lower than the tax rate. Therefore, government revenue as a fraction of GDP is lower in the permit economy.

Table 1: Constant-output Experiment

\begin{tabular}{lccc}
\hline & Permit & Tax & \% Diff. \\
\hline Regulated output & 0.293 & 0.293 & 0.00 \\
Regulated TFP & 1.864 & 2.071 & 11.06 \\
Unregulated output & 0.822 & 0.830 & 0.89 \\
Welfare & 0.650 & 0.654 & 0.66 \\
Relative price & 1.016 & 1.004 & -1.19 \\
& & & \\
Share of active entrepreneurs & 0.049 & 0.042 & \\
Share of labor in regulated & 0.192 & 0.184 & \\
Share of capital in regulated & 0.148 & 0.141 & \\
& & & \\
Gov revenue share of GDP & 0.009 & 0.020 & \\
\hline
\end{tabular}

Why are aggregate output and regulated sector TFP lower in the permit economy? Given 
that the permit economy has a larger share of entrepreneurs producing in equilibrium, the difference in TFP reflects the difference in the composition of active entrepreneurs. In the tax economy, the managerial skill cut-off is independent of asset endowment - see Equation (2), and only high-skill entrepreneurs choose to produce in equilibrium. This is no longer true in the permit economy because the managerial skill cut-off is increasing in the Lagrangian multiplier $\psi$ - see Equation (4). In other words, a high-skill entrepreneur could be inactive if she has low assets, while a high-asset low-skill entrepreneur might find it profitable to produce because she is less financially constrained. Hence, relative to taxes, with tradable permits output shifts from more productive entrepreneurs to less productive ones, thereby generating misallocation of capital and labor, which reduces TFP in the regulated sector.

To illustrate this point, we dissect the joint distribution of assets and managerial skills by percentile, and compute the share of regulated sector output produced by entrepreneurs in each percentile combination. The results for the permit and tax economies are presented in panels $\mathrm{A}$ and $\mathrm{B}$ of Table 2, respectively. In each panel, the rows correspond to different percentiles of asset endowments and columns correspond to percentiles of managerial skills. In both economies, only entrepreneurs with high enough managerial skills will produce, therefore, the second column is zero.

Comparing the last row of the two panels yields an immediate observation: entrepreneurs with lower managerial skills account for a higher share of output in the permit economy than in the tax economy. Consider entrepreneurs with skills in the top 0.5 percentile. These entrepreneurs account for 26 percent of total output in the permit economy, compared to 34 percent in the tax economy. In contrast, entrepreneurs with skills below the 97th percentile account for 25 percent of total output in the permit economy, compared to 18 percent in the tax economy. Therefore, using permits results in production shifting from high-skill entrepreneurs to low-skill ones.

Comparing the last column of the two panels yields another observation, that the distribution of output across assets are similar between the two economies. This is the result of the constant returns to scale technology. Conditional on producing, the amount of capital employed in production depends only on the entrepreneur's asset, and not on her managerial 
Table 2: Output Distribution by Assets and Managerial Skills

Panel A: permit Economy

\begin{tabular}{lcccccc}
\hline $\mathrm{a} \backslash \mathrm{z}$ & $(0,95]$ & $(95,97]$ & $(97,99]$ & $(99,99.5]$ & $(99.5,100]$ & sum \\
\hline$(0,25]$ & 0.000 & 0.022 & 0.034 & 0.012 & 0.020 & 0.087 \\
$(25,50]$ & 0.000 & 0.032 & 0.051 & 0.019 & 0.040 & 0.141 \\
$(50,75]$ & 0.000 & 0.050 & 0.058 & 0.028 & 0.054 & 0.191 \\
$(75,90]$ & 0.000 & 0.034 & 0.067 & 0.023 & 0.049 & 0.173 \\
$(90,100]$ & 0.000 & 0.114 & 0.128 & 0.062 & 0.105 & 0.409 \\
sum & 0.000 & 0.251 & 0.338 & 0.144 & 0.267 & 1.000 \\
\hline
\end{tabular}

Panel B: Tax Economy

\begin{tabular}{lcccccc}
\hline $\mathrm{a} \backslash \mathrm{z}$ & $(0,95]$ & $(95,97]$ & $(97,99]$ & $(99,99.5]$ & $(99.5,100]$ & sum \\
\hline$(0,25]$ & 0.000 & 0.014 & 0.033 & 0.012 & 0.031 & 0.089 \\
$(25,50]$ & 0.000 & 0.020 & 0.050 & 0.019 & 0.054 & 0.143 \\
$(50,75]$ & 0.000 & 0.034 & 0.057 & 0.029 & 0.066 & 0.186 \\
$(75,90]$ & 0.000 & 0.023 & 0.066 & 0.024 & 0.073 & 0.185 \\
$(90,100]$ & 0.000 & 0.088 & 0.126 & 0.063 & 0.119 & 0.396 \\
sum & 0.000 & 0.179 & 0.331 & 0.147 & 0.343 & 1.000 \\
\hline
\end{tabular}

skill. Hence, the distribution of output across assets is similar between the two economies.

In sum, there are two important takeaways from the constant-output experiment. First, in the presence of financial frictions, tradable permits are not equivalent to taxes for regulating output and consequently reducing emissions. Second, compared to taxes, reducing regulated sector output using tradable permits results in lower TFP, lower government revenue, and lower welfare. In sections below, we examine the robustness of these findings with respect to different parameter values.

\subsection{Different Tax Rates}

We now consider scenarios where the government faces different production (emission) targets for the regulated sector. To further reduce the output (emissions) in the regulated sector, the government could either raise the tax rate or reduce the aggregate supply of permits, and vice versa. In the baseline case, we considered a tax rate $\tau=0.075$. We now consider two different taxes: $\tau=0.05$ and $\tau=0.1$. Again, in each case we choose the aggregate supply of 
permits such that the permit economy has the same level of output in the regulated sector. Table 3 reports the differences in TFP, welfare, and government revenue between the tax economy and the permit economy.

Table 3: Constant-output Experiment with Different Tax Rates

\begin{tabular}{lccc}
\hline & $5 \%$ & $7.5 \%$ & $10 \%$ \\
\hline Tax rel. to permit (\% diff.) & & & \\
Regulated TFP & 8.052 & 11.063 & 13.419 \\
Unregulated output & 0.609 & 0.887 & 1.120 \\
Welfare & 0.451 & 0.655 & 0.826 \\
& & & \\
Revenue/GDP(\%) & & \\
Permit & 0.50 & 0.90 & 1.30 \\
Tax & 1.30 & 2.00 & 2.60 \\
\hline
\end{tabular}

As one might expect, the efficiency loss associated with permits is larger when the government faces a stronger demand to reduce regulated sector output. The difference in regulated sector TFP increases from 8 to 13 percent when the tax rate increases from 5 to 10 percent, and the difference in welfare increases from 0.45 to 0.83 percent. The reason is that when the government raises taxes to reduce regulated sector output, entrepreneurs with lower skills exit. Therefore, the remaining entrepreneurs have higher average skills. In this case, the distortions associated with permits are more costly because permits distort the optimal choices of more productive producers, and consequently generate a larger loss in efficiency. Across different tax rates, government revenue as a fraction of GDP in the permit economy remains roughly half of that in the tax economy.

\subsection{Correlation of Draws}

The borrowing constraint distorts the optimal choice of capital and labor, thereby generating misallocation. The importance of this mechanism depends, in part, on the joint distribution of assets and managerial skills. Broadly speaking, there could be three types of economies: one in which high-asset entrepreneurs are also highly skilled, one in which managerial skill is independent of asset, and one in which high-skill entrepreneurs tend to have lower assets. 
The question is in which case are the distortions associated with permits greater? In our baseline case, managerial skills and assets were uncorrelated (independent). Here we experiment with two alternative distributions of assets and managerial skills: one in which the correlation between assets and skills is 0.5 and in the other the correlation is -0.5 , and analyze the differences between the permit economy and the tax economy. In each case, we keep the tax rate $\tau=7.5 \%$ and choose the permit supply such that regulated sector output is the same across the two economies. Table 4 summarizes the findings.

Table 4: Constant-output Experiment with Correlated Draws

\begin{tabular}{lccc}
\hline & \multicolumn{3}{c}{ Asset-skill Correlation } \\
& -0.5 & 0 & 0.5 \\
\hline Tax rel. to permit (\% diff.) & & & \\
Regulated TFP & 19.465 & 11.063 & 9.280 \\
Unregulated output & 1.217 & 0.887 & 0.867 \\
Welfare & 0.893 & 0.655 & 0.645 \\
& & & \\
Revenue/GDP(\%) & & & \\
Permit & 1.10 & 0.90 & 0.90 \\
Tax & 2.00 & 2.00 & 1.90 \\
\hline
\end{tabular}

Permits are more distortive when assets and managerial skills are negatively correlated. This is because high-skill entrepreneurs now are more likely to be endowed with lower assets, and therefore permits further tighten the credit constraints. This results in less output produced by high-skill entrepreneurs and more by low-skill ones. Quantitatively, the effect is significant. The difference in regulated sector TFP between the tax and permit economies almost doubles when the correlation drops from 0 to -0.5. Similarly, the difference in unregulated sector output and welfare also increases by more than 20 percent. This mechanism is further confirmed when we increase the correlation from 0 to 0.5 , in which case more productive entrepreneurs are more likely to have high asset endowments. In this case, permits are less distortive. The difference in regulated sector TFP drops by 20 percent, and the differences in unregulated sector output and welfare drop by roughly 5 percent. In sum, using permits to regulate output results in greater misallocation in an economy where high-skill entrepreneurs are less likely to have high assets. 
To put this finding in a different perspective, it is useful to think about the dynamic economy similar to the one in Moll (2014), in which entrepreneurs could accumulate capital over time. In this case, the joint distribution of assets and managerial skills becomes endogenous. For example, consider an initial economy with negative correlation between assets and managerial skills. Since more productive entrepreneurs will accumulate more capital over time, assets and managerial skills will become more positively correlated over time. From this perspective, we could think of an economy with a negative correlation between assets and skills as a less developed economy, and one with a positive correlation as a more advanced economy. With this interpretation, our results suggest that, relative to taxes, using tradable permits to regulate output is more distortive for economies at earlier stages of development.

\subsection{Borrowing Constraints}

In our last robustness exercise, we experiment with different levels of borrowing constraint, $\lambda$, and examine the magnitude of the distortions from using permits rather than taxes to regulate output. Table 5 provides the difference between the tax and permit economies for three values of $\lambda$. While we used $\lambda=3$ in our baseline case, $\lambda=1$ implies that the entrepreneurs need to self-finance their capital use and purchase of permits, which corresponds roughly to

an economy like India or China that relies very little on external financing (Moll, 2014). We also consider $\lambda=6$, which corresponds to an economy like the United States. The distortion associated with permits is lower when producers face a looser borrowing constraint: with self-financing the regulated sector TFP is 12.4 percent lower in the permit than in the tax economy; while with entrepreneurs allowed to borrow upto six times their asset endowment, the TFP is about 10.4 percent lower in the permit economy. Relaxing the borrowing constraint allows high-skill low-asset entrepreneurs in the permit economy to buy permits and produce in the regulated sector, which results in higher TFP in the regulated sector. 
Table 5: Constant-output Experiment with Different Borrowing Constraints

\begin{tabular}{lccc}
\hline & \multicolumn{3}{c}{ Borrowing Constraint $(\lambda)$} \\
& 1 & 3 & 6 \\
\hline Tax rel. to Permit (\% diff.) & & & \\
Regulated TFP & 12.377 & 11.063 & 10.422 \\
Unregulated output & 1.102 & 0.887 & 0.825 \\
Welfare & 0.809 & 0.655 & 0.612 \\
& & & \\
Revenue/GDP(\%) & & & \\
Permit & 1.30 & 0.90 & 0.80 \\
Tax & 2.60 & 2.00 & 1.90 \\
\hline
\end{tabular}

\section{Conclusion}

Governments use either tradable permits or taxes to restrict emissions. The consensus in the literature is that, in the absence of frictions, these two instruments are equivalent. We examine the differential effects of tradable permits and taxes in a two-sector model, where output in the regulated sector is produced by entrepreneurs who differ in their endowment of managerial skills and assets. Government could use either a output tax or set up a market for tradable permits to restrict emissions by reducing output of the regulated sector. We show that taxes and tradable permits indeed generate identical outcomes in a frictionless version of our model.

This equivalence, however, breaks down when we introduce financial frictions in the form a borrowing constraint faced by entrepreneurs. In the tax economy, regardless of endowment of assets, only entrepreneurs with high managerial skills produce. This is no longer true for the permit economy because permits distort the optimal decisions of high-asset and low-asset entrepreneurs differently. An entrepreneur with high managerial skill would not produce if she has low assets to finance capital and permits. In contrast, a low managerial skill entrepreneur with high asset endowments may find it profitable to produce. Therefore, the permit economy has a higher share of low-skill entrepreneurs producing in equilibrium relative to the tax economy. This misallocation translates into lower TFP, higher price of the regulated good, lower welfare, and lower government revenue, compared to an economy that implements regulation with taxes. 
We parameterize the model and find that distortions from using tradable permits to restrict emissions are quantitatively significant. Further, we find that differences between the two instruments are larger when the target reduction in the regulated sector output is larger; when more entrepreneurs with high managerial skill are endowed with lower assets; and when the borrowing constraint is tighter. Our findings suggest that for regulating emissions in less developed countries taxes would be a better instrument than tradable permits.

\section{References}

Andersen, D. (2015). Credit constraints, technology upgrading, and the environment. Technical report, University of Alberta, Department of Economics.

Banerjee, A. V. and E. Duflo (2014). Do firms want to borrow more? testing credit constraints using a directed lending program. The Review of Economic Studies 81(2), 572607.

Beck, T., A. Demirgüç-Kunt, and R. Levine (2000). A new database on the structure and development of the financial sector. The World Bank Economic Review 14(3), 597-605.

Dardati, E. and J. Riutort (2015). Cap-and-trade and financial constraints: Is investment independent of permit holdings? Environmental and Resource Economics Forthcoming.

Goulder, L. H. and A. Schein (2013). Carbon taxes vs. cap and trade: A critical review. Technical report, National Bureau of Economic Research.

Guner, N., G. Ventura, and Y. Xu (2008). Macroeconomic Implications of Size-Dependent Policies. Review of Economic Dynamics 11(4), 721-744.

Herrendorf, B., R. Rogerson, and A. Valentinyi (2013). Two Perspectives on Preferences and Structural Transformation. American Economic Review 103(7), 2752-89.

Keohane, N. O. (2009). Cap and trade, rehabilitated: Using tradable permits to control us greenhouse gases. Review of Environmental Economics and Policy 3(1), 42-62. 
Lagakos, D. and M. E. Waugh (2013). Selection, Agriculture, and Cross-Country Productivity Differences. American Economic Review 103(2), 948-80.

Liu, Z., D. Guan, D. Crawford-Brown, Q. Zhang, K. He, and J. Liu (2013). Energy policy: A low-carbon road map for china. Nature 500(7461), 143-145.

Midrigan, V. and D. Y. Xu (2014). Finance and Misallocation: Evidence from Plant-Level Data. American Economic Review 104 (2), 422-58.

Moll, B. (2014). Productivity losses from financial frictions: Can self-financing undo capital misallocation? The American Economic Review 104(10), 3186-3221.

Nordhaus, W. D. (2007). To tax or not to tax: Alternative approaches to slowing global warming. Review of Environmental Economics and Policy 1(1), 26-44.

Rajan, R. G. and L. Zingales (1998). Financial dependence and growth. The American Economic Review 88(3), 559-586.

Restuccia, D. and R. Rogerson (2008). Policy Distortions and Aggregate Productivity with Heterogeneous Plants. Review of Economic Dynamics 11(4), 702-720.

Restuccia, D. and R. Rogerson (2013). Misallocation and productivity. Review of Economic Dynamics 16(1), 1 - 10 .

Tombe, T. and J. Winter (2015). Environmental policy and misallocation: The productivity effect of intensity standards. Journal of Environmental Economics and Management 72, $137-163$.

Weisbach, D. A. (2009). Instrument choice is instrument design. U of Chicago Law $\mathscr{B}$ Economics, Olin Working Paper (490). 